\title{
Effect of Manuring Techniques on Soil Health, Yield and Economics of Maize-Wheat Cropping System under UKP Command
}

\author{
K.A. Hiremath*, A.S. Halepyati, M.A. Bellakki, B.M. Chittapur, \\ P.H. Kuchanur, B.M. Dodamani and Ameregouda \\ Department of Agronomy, University of Agricultural Sciences, Raichur - 584104 \\ (Karnataka), India \\ *Corresponding author
}

\section{Keywords}

Brown manuring, Green manuring,

System

productivity,

Residual effect,

Succeeding crop

Article Info

Accepted:

04 January 2019

Available Online:

10 February 2019

\section{A B S T R A C T}

A field investigation was carried out during kharif and rabi seasons of 2013-14 and 201415 at Agricultural Research Station, Bheemarayanagudi to study the effect of manuring techniques on soil health, yield and economics of maize - wheat cropping system under irrigation. The results indicated that the grain and stover yield of maize $\left(55.35 \mathrm{q} \mathrm{ha}^{-1}\right.$ and $70.23 \mathrm{q} \mathrm{ha}^{-1}$, respectively) were significantly higher with sunnhemp as green manuring in 1:2 row proportions compared to sole maize $(60 \mathrm{~cm} \times 20 \mathrm{~cm})$ without manuring $(43.85 \mathrm{q}$ $\mathrm{ha}^{-1}$ and $50.18 \mathrm{q} \mathrm{ha}^{-1}$, respectively) and it was found on par with sunnhemp, cowpea and dhaincha as brown manuring in 1:1 and 1: 2 row proportions in maize. The residual effect of legume species used as green and brown manuring in preceeding maize was affected significantly on succeeding wheat crop. Sunnhemp as green manuring in 1:2 row proportion registered significantly higher grain yield and straw yield of wheat ( $38.45 \mathrm{q} \mathrm{ha}^{-1}$ and $70.23 \mathrm{q} \mathrm{ha}^{-1}$, respectively) and it was on par with sunnhemp as brown manuring in 1:2 row proportion. The lowest grain and straw yield of wheat $\left(18.35 \mathrm{q} \mathrm{ha}^{-1}\right.$ and $36.4 \mathrm{q} \mathrm{ha}{ }^{-1}$, respectively) were recorded in sole maize plot $(60 \mathrm{~cm} \times 20 \mathrm{~cm})$ without manuring in preceeding season. The maize equivalent yield of wheat and system productivity followed same trend as that of yields obtained with both the crops. Varying levels of $\mathrm{N}$ did not vary on the performance of wheat. However, yield of wheat was recorded in $125 \%$ RDN. Significantly higher organic carbon and available NPK were noticed with sunnhemp as green manuring in 1:2 row proportion compared to sole maize. Higher net returns and BC ratio were recorded with sunnhemp as green manuring in 1:2 row proportion (Rs.89,476 $\mathrm{ha}^{-1}$ and 2.18, respectively) followed by sunnhemp as brown manuring 1:2 row proportions (Rs. 85,820 ha ${ }^{-1}$ and 2.08, respectively). The lowest net returns and $\mathrm{BC}$ ratio (Rs. 45,735 $\mathrm{ha}^{-1}$ and 1.16, respectively) were recorded in sole maize $(60 \mathrm{~cm} \times 20 \mathrm{~cm})-$ wheat sequence. The different nitrogen levels did not differ.

\section{Introduction}

Rice - Rice is the predominant cropping system being adopted by the farmers' long back in upper krishna and tunga bhadra projects being the largest irrigation projects in Karnataka. At present, the system being practiced is creating lot of problems with 
respect to sustainability in crop production and lands are increasingly becoming unproductive. Of the several options available, adoption of alternate novel crop rotation appears to be promising. Maize has become an alternate crop to be integrated in rice-rice system replacing one rice crop especially during winter or replacing rice rice by alternate and profitable system involving maize - wheat sequence. Though, there are some indications of stagnation or even decline in the productivity of this cropping system due to decreased soil organic matter, over exploitation of nutrients reserve, loss of nutrients and non availability of cost effective fertilizer. Further, the application of inorganic fertilizers even in balanced form may not sustain soil fertility and productivity under continuous cropping. However, use of inorganic fertilizers in combination with green manure and crop residues may improve the soil productivity (Sharma and Prasad, 2001 and Mankotia, 2007). Among the various factors for improving productivity, organic carbon and available major nutrients play vital role by participating in different metabolic activities in plant system. The improved genotypes of cereals and cropping systems need more quantities of major nutrients for full exploitation of their potential to produce the yields. Incorporation of farm waste as biological as well as practice of green manuring in cereals is viable options, which improves the productivity and partially substitutes the fertilizer nitrogen requirement of the subsequent crop. Adequate information is available on the response of maize and wheat to either inorganic or organic fertilizers on single crop.

Green manuring is a renewable source of input for building up soil fertility and supplementing plant nutrients contained in the biomass. Such biomass can be obtained either by growing in situ and incorporated or grown elsewhere and brought in for incorporation in the field as green manuring. However such practice is not popular among the farming community particularly in arable field crops and cropping systems. This is because farmer neither gets enough window in the growing season to grow a green manure crops nor has enough financial resources to spend on labours. Never the less it can be popularized as a low cost effective technology to save on fertilizer and other inputs. At present, a new concept called brown manuring technique is gaining popularity in rice ecosystem. Brown manuring is the practice to reduce weed pressure, as brown manuring acts as a cover crop in suppressing weed growth effectively at the initial growth stage (Kumar and Mukharjee, 2011). The post emergence herbicidal spray on green manure leaves results in loss of chlorophyll in leaves leading to browning and hence the same is referred brown manuring (Tanwar et al., 2010). It can be achieved through raising green manure crops such as Sesbania (dhaincha), sunnhemp etc., as inter crop and killing the same later by application of post emergence herbicides. The suppressed residue as manure is allowed to remain in the field. But at the same time its use is very much required to enhance the sustained accumulation by improving the soil fertility and supplementing the plant nutrients in arable crops practicing cereal-cereal and cereal-legume cropping systems in rainfed as well as irrigated condition.

Therefore, an investigation was undertaken to study the effect of manuring techniques on soil health, yield and economics of maize wheat cropping system under irrigated condition.

\section{Materials and Methods}

An experiment was conducted during kharif and rabi seasons of 2013-14 and 2014-15 at Agricultural Research Station, Bheemarayanagudi, University of 
Agricultural Sciences, Raichur, Karnataka. The soil of the experimental site was medium deep black soil with $7.80 \mathrm{pH}$. The soil was low in available nitrogen (243 kg ha- 1$)$, high in available phosphorus ( $\left.49 \mathrm{~kg} \mathrm{ha}^{-1}\right)$ and high in available potassium (337 $\left.\mathrm{kg} \mathrm{ha}^{-1}\right)$. The organic carbon content of the soil was low $(0.43 \%)$. The Agricultural Research Station represents the UKP command where in rice rice, chilli and cotton are the predominant crops. The rainfall during cropping seasons in the year 2013 - 14 and 2014 - 15 received 759 $\mathrm{mm}$ and $646 \mathrm{~mm}$ respectively. The experiment was laid out in a Randomized Complete Block Design consisting of nine treatments namely $\mathrm{M}_{1}$ - Control $(60 \mathrm{~cm}$ x 20 $\mathrm{cm})$ as sole maize, $\mathbf{M}_{2}$ - Maize + sunnhemp as green manuring (1:1), $\mathrm{M}_{3}$ - Maize + sunnhemp as green manuring (1:2), $\mathbf{M}_{4}$ Maize + sunnhemp as brown manuring (1:1), $\mathrm{M}_{5}$ - Maize + sunnhemp as brown manuring (1:2), $\mathrm{M}_{6}$ - Maize + cowpea as brown manuring (1:1), $\mathbf{M}_{7}$ - Maize + cowpea as brown manuring (1:2), $\mathrm{M}_{8}$ - Maize + dhaincha as brown manuring (1:1), $\mathrm{M}_{9}$ - Maize + dhaincha as brown manuring (1:2) during kharif season.

During rabi season, these nine treatments become main plots and sub plots consist of three $\mathrm{N}$ levels $(75,100$ and $125 \% \mathrm{RDN})$ to wheat for which, split plot design was laid out in three replications. The hybrid 900M was used for maize and the variety DWR 198 was used for wheat. The recommended dose of fertilizer 150: 75: $37.5 \mathrm{NPK} \mathrm{ha}^{-1}$ was used for maize. The fertilizers were applied to wheat as per the treatments. Pre emergent herbicide pendimethalin 30 EC @ $2.5 \mathrm{~kg} \mathrm{ha}^{-1}$ was used to control weeds in initial stage in maize intercropped with green manure crops. Post emergent herbicide 2, 4 - D $80 \% @ 1.25 \mathrm{~kg}$ $\mathrm{ha}^{-1}$ was used for suppressing the green manure crops and incorporated them as brown manure after harvest of maize in the place where green manure was grown. Other agronomic practices were followed commonly in all the treatments as per the recommendations.

\section{Results and Discussion}

\section{Effect of manuring techniques on maize}

The data revealed that the grain and stover yield of maize did not differ due to green and brown manuring treatments during 2013-14 and differed significantly during 2014-15. This clearly indicated that legumes have positive influence on maize yields when grown as intercrops for green manuring than sole maize. Among all the treatments in the investigation, the green manuring treatments maize + sunnhemp as GM in 1:2 row proportion $\left(\mathrm{M}_{3}\right)$ followed by maize + sunnhemp as GM in 1:1 row proportion recorded the highest grain yield of maize of 55.35 and $53.37 \mathrm{q} \mathrm{ha}$ respectively. The increase in grain yield of maize intercropped with sunnhemp in 1:1 and 1:2 row proportions for green manuring purpose was 23.96 per cent over sole maize. Dasaraddi (1998), Nooli and Chittapur, (2001) and Jat et al., (2010) also reported similar results.

Among different brown manuring practices, the treatment maize + sunnhemp as BM in 1:2 row proportion recorded higher grain and stover yield $\left(53.40 \mathrm{q} \mathrm{ha}^{-1}\right.$ and $67.00 \mathrm{q} \mathrm{ha}^{-1}$ respectively) followed by maize + sunnhemp as $\mathrm{BM}$ in 1:1 row proportion, maize + cowpea as $\mathrm{BM}$ in 1:1 row proportion, maize + cowpea as $\mathrm{BM}$ in 1:2 row proportion, maize + dhaincha as $\mathrm{BM}$ in 1:1 row proportion and maize + dhaincha as BM in 1:2 proportion. All these treatments were on par with each other and also with maize + sunnhemp as GM in 1:2 row proportions. Further, all these treatments increased the grain yields of maize by $21.78,19.54,13.79,15.89,9.87$ and 11.13 per cent respectively over sole maize $(60 \mathrm{~cm}$ x $20 \mathrm{~cm}$ ) which recorded the lowest grain and 
stover yield (43.85 q ha ${ }^{-1}$ and $50.18 \mathrm{q} \mathrm{ha}^{-1}$ respectively). The improvement in grain and stover yield of maize in association with sunnhemp, cowpea and dhaincha grown as intercrops in 1:1 and 1:2 row proportions for green and brown manuring may be further attributed to favourable effect of higher organic carbon and available NPK. The results are in conformity with the findings of Aslam et al., (2008), Sharma et al., (2008) and Satyaprakash and Phoolchand, (2011).

Effect of manuring techniques on succeeding wheat

With respect to green manuring, sunnhemp in $1: 1$ and $1: 2$ row proportion recorded 50.12 and 52.27 per cent higher grain yield of wheat respectively over without green manuring. The findings are in conformity with the findings of Dasaraddi (1998). Further, this result also corroborated with the findings of Nooli and Chittapur (2001) who studied in maize - safflower sequence cropping. With respect to brown manuring techniques, the maximum grain yield of wheat with brown manuring of sunnhemp in 1:1 (35.71 $\left.\mathrm{q} \mathrm{ha}^{-1}\right)$ and $1: 2$ row proportions in preceding maize (37.79 q ha ${ }^{-1}$ ) was noticed. The brown manuring of cowpea grown in 1:1 and 1:2 row proportions in preceding maize was found to be next best treatments. All these treatments recorded significantly higher grain yield over yield obtained with brown manuring of dhaincha in $1: 1\left(25.62 \mathrm{q} \mathrm{ha}^{-1}\right)$ and $1: 2\left(27.56 \mathrm{q} \mathrm{ha}^{-1}\right)$ row proportions in preceeding maize.

Brown manuring of sunnhemp in $1: 1$ and $1: 2$ row proportions recorded 51.44 and 48.61 per cent higher grain yield of wheat over control plot. While brown manuring of cowpea in $1: 1$ and 1:2 row proportion recorded 42.75 and 46.84 per cent higher yield than control plot. While, brown manuring of dhaincha in maize failed to give satisfactory yield levels of wheat. The information on the effect of brown manuring on succeeding crop is very meager. However, similar kind of influence on succeeding crop was observed with green manuring practice in kharif crop. Grewal et al., (1992) studied the response of wheat to residual effect of green manuring as much as $0.5 \mathrm{t} \mathrm{ha}^{-1}$. Thus, green manuring augmented total productivity of maize - wheat system by $2.1 \mathrm{t} \mathrm{ha}^{-1}$. The findings of Gangawar et al., (2004) also confirmed closely with the findings of Jat et al., (2010) who observed that the residual effect of sesbania green manuring + wheat straw and sesbania green manuring alone used in preceding maize affected significantly the growth and yield of succeeding wheat. Harvest index did not differ due to the treatments.

Different nitrogen levels to wheat crop had no significant difference. Non significant differences for grain and straw yield of wheat were recorded due to interaction of green and brown manuring of legume species and various nitrogen levels.

\section{Effect of manuring techniques on maize equivalent yield and system productivity}

The pooled data revealed that maize equivalent yield and system productivity were followed same trend as that of yields obtained with both crops due to treatments. Significantly higher maize equivalent yield was noticed with maize + sunnhemp as GM (1:2) $\left(43.82 \mathrm{q} \mathrm{ha}^{-1}\right)$. The treatments control $(60 \mathrm{~cm} \times 20 \mathrm{~cm})$, maize + sunnhemp as BM (1:1), maize + sunnhemp as BM (1:2), maize + cowpea as BM (1:2) were found on par with maize + sunnhemp as GM (1:2) and they were found significantly superior than maize + dhaincha as BM (1:1) and maize + dhaincha as BM (1:2) which were in turn found on par each other. The treatment maize + cowpea as BM (1:1) expressed its yield level on par with maize + sunnhemp as GM (1:1) and maize + 
sunnhemp as BM (1:1). Significantly the lowest maize equivalent yield was registered with control $(60 \mathrm{~cm} \times 20 \mathrm{~cm})\left(20.95 \mathrm{q} \mathrm{ha}^{-1}\right)$ among all the treatments. The various levels of nitrogen did not differ for maize equivalent yield. However, numerically the higher maize equivalent yield was noticed with $125 \%$ RDN (37.51 $\mathrm{q} \mathrm{ha}^{-1}$ ) and lowest yield was $75 \%$ RDN (35.18 $\mathrm{q} \mathrm{ha}^{-1}$ ). The interaction effect due to manuring treatments as well as varying levels of nitrogen did not differ significantly.

Significantly higher system productivity was recorded with maize + sunnhemp as GM (1:2) $\left(99.17 \mathrm{q} \mathrm{ha}^{-1}\right)$ as compared to control $(60 \mathrm{~cm}$ x $20 \mathrm{~cm})$, maize + cowpea as BM (1:1), maize + dhaincha as BM (1:1) and maize + dhaincha as $\mathrm{BM}(1: 2)$. The treatments maize + sunnhemp as GM (1:1), maize + sunnhemp as BM (1:1), maize + sunnhemp as BM (1:2) and maize + cowpea as BM (1:2) were found on par with maize + sunnhemp as GM (1:2). The treatment maize + cowpea as BM (1:1) was found on par with maize + dhaincha as BM (1:1) and maize + dhaincha as BM (1:2) found significantly superior than control (60 $\mathrm{cm}$ x $20 \mathrm{~cm})$. Significantly the lowest system productivity was noticed with control $(60 \mathrm{~cm}$ x $20 \mathrm{~cm})\left(64.80 \mathrm{q} \mathrm{ha}^{-1}\right)$. The different nitrogen levels did not differ significantly. However, $125 \%$ RDN was recorded numerically higher system productivity ( $\left.88.17 \mathrm{q} \mathrm{ha}^{-1}\right)$. The lowest system productivity ( $\left.85.85 \mathrm{q} \mathrm{ha}^{-1}\right)$ was noticed with $75 \%$ RDN. The interaction effect due to manuring treatments as well as varying levels of nitrogen did not differ.

\section{Effect of manuring techniques on soil fertility status}

The changes in organic carbon and availability of major nutrients revealed that there was a significant increase in organic carbon, available nitrogen, phosphorus and potassium contents in all manured plots as compared to control (sole maize with $60 \mathrm{~cm} \mathrm{x}$
$20 \mathrm{~cm}$ without manuring). The treatments maize + sunnhemp as GM (1:1), maize + sunnhemp as GM (1:2), maize + sunnhemp as BM (1:1) and maize + sunnhemp as BM (1:2) recorded significantly higher organic carbon $(0.47 \%)$ and they were found on par with rest of the treatments except control $(60 \mathrm{~cm} \times 20$ $\mathrm{cm})$ which recorded lowest organic carbon of $0.39 \%$. The treatment maize + sunnhemp as GM (1:2) recorded significantly higher available nitrogen, phosphorus and potassium $\left(259.00 \mathrm{~kg} \mathrm{ha}^{-1} 45.67 \mathrm{~kg} \mathrm{ha}^{-1}\right.$ and $124.04 \mathrm{~kg}$ ha'1, respectively) and was found on par with rest of the treatments except control $(60 \mathrm{~cm} \mathrm{x}$ $20 \mathrm{~cm}$ ) which recorded lowest available nitrogen, phosphorus and potassium of 219.10 $\mathrm{kg} \mathrm{ha}{ }^{-1}$. $38.82 \mathrm{~kg} \mathrm{ha}^{-1}$ and $105.06 \mathrm{~kg} \mathrm{ha}^{-1}$, respectively. These results in confirmity with findings of Samar Singh et al., (2007) and Satyaprakash and Phoolchand (2011).

\section{Economics of manuring techniques in maize - wheat cropping system}

The net returns and $\mathrm{BC}$ ratio were differed significantly among the green and brown manuring practices under maize - wheat cropping system. Green manuring of sunnhemp grown with maize in 1:2 ratio (Rs.89,476 $\mathrm{ha}^{-1}$ ) followed by brown manuring of sunnhemp grown with maize in 1:2 ratio (Rs.85,820 ha $\mathrm{ha}^{-1}$ and green manuring of sunnhemp grown with maize in 1:1 ratio (Rs.84,575 $\mathrm{ha}^{-1}$ ) recorded significantly higher net returns over other legumes used for green and brown manuring purpose. The $\mathrm{B}: \mathrm{C}$ ratio was also higher with green manuring of sunnhemp grown with maize in 1:2 ratio (2.18) followed by brown manuring of sunnhemp grown with maize in 1:2 ratio (2.08) and green manuring of sunnhemp grown with maize in $1: 1$ ratio (2.07). Jat et al., (2010) also reported higher net returns and $\mathrm{B}: \mathrm{C}$ with green manuring. The different nitrogen levels did not differ with respect to the economics (Table 1-4). 
Table.1 Organic carbon, available N, P and K of soil in different green and brown manuring crops in maize - wheat cropping System

\begin{tabular}{|c|c|c|c|c|c|c|c|c|c|c|c|c|}
\hline \multirow[t]{2}{*}{ Treatment } & \multicolumn{3}{|c|}{$\begin{array}{c}\text { Organic carbon }(\%) \text { at } 90 \\
\text { DAS }\end{array}$} & \multicolumn{3}{|c|}{$\begin{array}{l}\text { Available } \mathbf{N} \\
\left(\mathrm{kg} \mathrm{ha}^{-1}\right)\end{array}$} & \multicolumn{3}{|c|}{$\begin{array}{l}\text { Available P } \\
\left(\mathrm{kg} \mathrm{ha}^{-1}\right)\end{array}$} & \multicolumn{3}{|c|}{$\begin{array}{l}\text { Available K } \\
\left(\mathrm{kg} \mathrm{ha}^{-1}\right)\end{array}$} \\
\hline & $\begin{array}{c}2013- \\
14\end{array}$ & $\begin{array}{c}\text { 2014- } \\
15\end{array}$ & Pooled & $\begin{array}{c}2013- \\
14\end{array}$ & $\begin{array}{c}\text { 2014- } \\
15\end{array}$ & Pooled & $\begin{array}{c}2013- \\
14\end{array}$ & $\begin{array}{c}2014- \\
15\end{array}$ & Pooled & 2013-14 & 2014-15 & Pooled \\
\hline$M_{1}$ - Control $(60 \mathrm{~cm} \times 20 \mathrm{~cm})$ & 0.41 & 0.37 & 0.39 & 222.50 & 215.70 & 219.10 & 38.60 & 39.00 & 38.82 & 103.33 & 106.80 & 105.06 \\
\hline $\mathrm{M}_{2}-$ Maize + Sunnhemp as GM (1:1) & 0.43 & 0.50 & 0.47 & 247.80 & 258.05 & 252.90 & 42.70 & 46.67 & 44.67 & 119.71 & 122.51 & 121.11 \\
\hline$M_{3}$ - Maize + Sunnhemp as GM (1:2) & 0.44 & 0.50 & 0.47 & 251.10 & 266.90 & 259.00 & 43.70 & 47.67 & 45.67 & 122.78 & 125.31 & 124.04 \\
\hline $\mathrm{M}_{4}$ - Maize + Sunnhemp as BM $(1: 1)$ & 0.43 & 0.50 & 0.47 & 247.20 & 257.80 & 252.50 & 41.00 & 45.33 & 43.17 & 119.32 & 120.78 & 120.05 \\
\hline $\mathrm{M}_{5}$ - Maize + Sunnhemp as BM (1:2) & 0.44 & 0.50 & 0.47 & 248.30 & 263.30 & 255.80 & 43.50 & 47.67 & 45.58 & 122.51 & 124.84 & 123.67 \\
\hline$M_{6}-$ Maize + Cowpea as BM (1:1) & 0.43 & 0.49 & 0.46 & 241.60 & 252.00 & 246.80 & 39.50 & 44.00 & 41.77 & 113.92 & 114.68 & 114.30 \\
\hline$M_{7}$ - Maize + Cowpea as BM (1:2) & 0.43 & 0.50 & 0.47 & 245.10 & 255.30 & 250.20 & 40.10 & 44.33 & 42.22 & 114.65 & 116.22 & 115.40 \\
\hline$M_{8}$ - Maize + Dhaincha as BM (1:1) & 0.41 & 0.48 & 0.45 & 240.20 & 250.00 & 245.10 & 39.00 & 43.33 & 41.17 & 111.55 & 113.08 & 112.32 \\
\hline $\mathrm{M}_{9}$ - Maize + Dhaincha as BM (1:2) & 0.42 & 0.48 & 0.45 & 241.40 & 251.30 & 246.40 & 39.10 & 44.00 & 41.55 & 111.92 & 113.47 & 112.70 \\
\hline S.Em \pm & 0.02 & 0.02 & 0.02 & 9.53 & 9.10 & 8.90 & 1.70 & 1.35 & 1.27 & 6.94 & 3.84 & 3.01 \\
\hline C.D. (0.05) & NS & 0.07 & 0.06 & NS & 29.20 & 26.30 & NS & 4.07 & 3.84 & NS & 11.62 & 9.11 \\
\hline
\end{tabular}

Note: GM - Green manuring, BM - Brown manuring 
Table.2 Grain yield, stover yield and harvest index of maize and wheat (straw yield for wheat) as influenced by different green and brown manuring practices in maize - wheat cropping system

\begin{tabular}{|c|c|c|c|c|c|c|c|c|c|}
\hline \multirow{3}{*}{ Treatment } & \multicolumn{9}{|c|}{ Maize } \\
\hline & \multicolumn{3}{|c|}{$\begin{array}{c}\text { Grain yield } \\
\left(\mathbf{q} \text { ha- }^{1}\right)\end{array}$} & \multicolumn{3}{|c|}{$\begin{array}{l}\text { Stover yield } \\
\quad\left(\mathbf{q} \mathbf{h a}^{-1}\right)\end{array}$} & \multicolumn{3}{|c|}{ Harvest index } \\
\hline & 2013-14 & $\begin{array}{c}2014- \\
15\end{array}$ & Pooled & $\begin{array}{c}2013- \\
14\end{array}$ & $\begin{array}{c}2014- \\
15\end{array}$ & Pooled & $\begin{array}{c}2013- \\
14\end{array}$ & $\begin{array}{c}2014- \\
15\end{array}$ & Pooled \\
\hline \multicolumn{10}{|l|}{ Main plots $(\mathbf{M})$} \\
\hline$M_{1}-$ Maize alone $(60 \mathrm{~cm} \times 20 \mathrm{~cm})$ & 53.83 & 33.87 & 43.85 & 62.50 & 37.87 & 50.18 & 0.46 & 0.47 & 0.47 \\
\hline $\mathrm{M}_{2}$ - Maize + Sunnhemp as GM (1:1) & 56.70 & 50.03 & 53.37 & 71.40 & 59.47 & 65.43 & 0.44 & 0.46 & 0.45 \\
\hline $\mathrm{M}_{3}-$ Maize + Sunnhemp as GM (1:2) & 57.77 & 52.93 & 55.35 & 73.80 & 66.67 & 70.23 & 0.44 & 0.45 & 0.44 \\
\hline $\mathrm{M}_{4}-$ Maize + Sunnhemp as BM $(1: 1)$ & 56.70 & 48.13 & 52.42 & 70.43 & 58.93 & 64.68 & 0.45 & 0.46 & 0.45 \\
\hline$M_{5}$ - Maize + Sunnhemp as BM $(1: 2)$ & 56.77 & 50.03 & 53.40 & 71.73 & 62.27 & 67.00 & 0.44 & 0.45 & 0.44 \\
\hline$M_{6}-$ Maize + Cowpea as BM $(1: 1)$ & 55.33 & 44.47 & 49.90 & 67.40 & 53.96 & 60.68 & 0.45 & 0.46 & 0.45 \\
\hline $\mathrm{M}_{7}$ - Maize + Cowpea as BM (1:2) & 55.57 & 46.07 & 50.82 & 68.00 & 56.27 & 62.13 & 0.45 & 0.45 & 0.45 \\
\hline $\mathrm{M}_{8}$ - Maize + Dhaincha as BM (1:1) & 54.53 & 41.83 & 48.18 & 63.43 & 49.87 & 56.65 & 0.46 & 0.46 & 0.46 \\
\hline$M_{9}$ - Maize + Dhaincha as BM (1:2) & 55.13 & 42.33 & 48.73 & 65.43 & 50.67 & 58.05 & 0.46 & 0.46 & 0.46 \\
\hline S.Em \pm & 3.96 & 3.51 & 2.63 & 4.47 & 4.94 & 3.16 & 0.03 & 0.02 & 0.02 \\
\hline $\mathrm{CD}(\mathrm{P}=\mathbf{0 . 0 5})$ & NS & 10.62 & 6.83 & NS & 14.95 & 9.57 & NS & NS & NS \\
\hline \multicolumn{10}{|l|}{ Sub plots $(\mathbf{N})$} \\
\hline $\mathrm{N}_{1}-75 \%$ RDN & - & - & - & - & - & - & - & - & - \\
\hline $\mathrm{N}_{2}-100 \% \mathrm{RDN}$ & - & - & - & - & - & - & - & - & - \\
\hline $\mathrm{N}_{3}-125 \% \mathrm{RDN}$ & - & - & - & - & - & - & - & - & - \\
\hline S.Em \pm & - & - & - & - & - & - & - & - & - \\
\hline $\mathrm{CD}(\mathrm{P}=\mathbf{0 . 0 5})$ & - & - & - & - & - & - & - & - & - \\
\hline Interaction (M x N) & - & - & - & - & - & - & - & - & - \\
\hline
\end{tabular}

Note: GM - Green manuring, BM - Brown manuring 
Table.3 Grain yield, straw yield and harvest index of wheat as influenced by different green and brown manuring practices and N levels in maize - wheat cropping system

\begin{tabular}{|c|c|c|c|c|c|c|c|c|c|}
\hline \multirow{3}{*}{ Treatment } & \multicolumn{9}{|c|}{ Wheat } \\
\hline & \multicolumn{3}{|c|}{$\begin{array}{c}\text { Grain yield } \\
\left(\mathrm{q} \mathrm{ha-}{ }^{1}\right)\end{array}$} & \multicolumn{3}{|c|}{$\begin{array}{l}\text { Straw yield } \\
\qquad\left(\mathbf{q} \mathbf{h a}^{-1}\right)\end{array}$} & \multicolumn{3}{|c|}{ Harvest index } \\
\hline & $\begin{array}{c}2013- \\
14\end{array}$ & $\begin{array}{c}2014- \\
15\end{array}$ & Pooled & $\begin{array}{c}2013- \\
14\end{array}$ & 2014-15 & Pooled & 2013-14 & $\begin{array}{c}2014- \\
15\end{array}$ & Pooled \\
\hline \multicolumn{10}{|l|}{ Main plots (M) } \\
\hline$M_{1}-$ Maize alone $(60 \mathrm{~cm} \times 20 \mathrm{~cm})$ & 20.13 & 16.57 & 18.35 & 36.37 & 36.62 & 36.49 & 0.36 & 0.31 & 0.34 \\
\hline$M_{2}$ - Maize + Sunnhemp as GM $(1: 1)$ & 38.67 & 34.91 & 36.79 & 69.26 & 65.31 & 67.28 & 0.35 & 0.35 & 0.35 \\
\hline$M_{3}-$ Maize + Sunnhemp as GM (1:2) & 40.13 & 36.77 & 38.45 & 72.01 & 68.46 & 70.23 & 0.36 & 0.35 & 0.35 \\
\hline $\mathrm{M}_{4}-$ Maize + Sunnhemp as BM (1:1) & 37.23 & 34.18 & 35.71 & 67.28 & 63.54 & 64.41 & 0.36 & 0.35 & 0.35 \\
\hline$M_{5}$ - Maize + Sunnhemp as BM $(1: 2)$ & 39.58 & 36.01 & 37.79 & 69.90 & 66.48 & 68.19 & 0.36 & 0.35 & 0.36 \\
\hline$M_{6}-$ Maize + Cowpea as BM $(1: 1)$ & 34.20 & 29.90 & 32.05 & 58.89 & 56.00 & 57.44 & 0.37 & 0.35 & 0.36 \\
\hline$M_{7}$ - Maize + Cowpea as BM (1:2) & 36.20 & 32.83 & 34.52 & 64.74 & 61.48 & 63.11 & 0.36 & 0.35 & 0.35 \\
\hline M8 - Maize + Dhaincha as BM (1:1) & 27.26 & 23.98 & 25.62 & 46.18 & 44.52 & 45.35 & 0.38 & 0.35 & 0.36 \\
\hline $\mathrm{M}_{9}$ - Maize + Dhaincha as BM (1:2) & 29.32 & 25.79 & 27.56 & 51.10 & 48.32 & 49.71 & 0.36 & 0.35 & 0.35 \\
\hline S.Em \pm & 2.20 & 1.88 & 1.86 & 3.96 & 2.64 & 2.94 & 0.02 & 0.02 & 0.02 \\
\hline $\mathrm{CD}(\mathrm{P}=\mathbf{0 . 0 5})$ & 6.64 & 5.69 & 5.62 & 11.97 & 7.99 & 8.89 & NS & NS & NS \\
\hline \multicolumn{10}{|l|}{ Sub plots $(\mathbf{N})$} \\
\hline $\mathrm{N}_{1}-75 \% \mathrm{RDN}$ & 32.64 & 29.07 & 30.86 & 56.48 & 54.01 & 55.25 & 0.37 & 0.35 & 0.36 \\
\hline $\mathrm{N}_{2}-100 \% \mathrm{RDN}$ & 33.59 & 30.11 & 31.85 & 60.41 & 57.70 & 59.06 & 0.35 & 0.34 & 0.35 \\
\hline $\mathrm{N}_{3-1} 125 \%$ RDN & 34.67 & 31.13 & 32.90 & 61.68 & 58.53 & 60.11 & 0.36 & 0.35 & 0.35 \\
\hline S.Em \pm & 1.56 & 1.55 & 1.37 & 1.76 & 1.71 & 1.26 & 0.01 & 0.01 & 0.01 \\
\hline $\mathrm{CD}(\mathrm{P}=0.05)$ & NS & NS & NS & NS & NS & 3.63 & NS & NS & NS \\
\hline \multicolumn{10}{|l|}{ Interaction $(\mathbf{M} \times \mathbf{N})$} \\
\hline S.Em \pm & 3.80 & 3.26 & 3.22 & 5.85 & 4.57 & 4.26 & 0.03 & 0.02 & 0.02 \\
\hline C.D. (0.05) & NS & NS & NS & NS & NS & NS & NS & NS & NS \\
\hline
\end{tabular}

Note: GM - Green manuring, BM - Brown manuring 
Table.4 Maize equivalent yield of wheat, system productivity and economics of maize - wheat cropping system as influenced by different green and brown manuring practices and nitrogen levels (Mean of two years)

\begin{tabular}{|c|c|c|c|c|c|}
\hline Treatment & $\begin{array}{c}\text { Maize } \\
\text { equivalent yield } \\
\text { of wheat }\left(\mathrm{q} \mathrm{ha}^{-1}\right)\end{array}$ & $\begin{array}{l}\text { System } \\
\text { productivity } \\
\left(\mathbf{q} \mathbf{h a}^{-1}\right)\end{array}$ & $\begin{array}{c}\text { Cost of } \\
\text { cultivation of } \\
\text { maize - wheat } \\
\text { system } \\
\left(\text { Rs. ha }{ }^{-1}\right)\end{array}$ & $\begin{array}{l}\text { Net return } \\
\left(\text { Rs. ha }{ }^{-1}\right)\end{array}$ & $\begin{array}{l}\mathrm{B}: \mathrm{C} \\
\text { ratio }\end{array}$ \\
\hline \multicolumn{6}{|l|}{ Main plots (M) } \\
\hline$M_{1}-$ Maize alone $(60 \mathrm{~cm} \times 20 \mathrm{~cm})$ & 20.95 & 64.80 & 39538 & 45735 & 1.16 \\
\hline$M_{2}$ - Maize + Sunnhemp as GM (1:1) & 41.94 & 95.30 & 40938 & 84575 & 2.07 \\
\hline$M_{3}$ - Maize + Sunnhemp as GM (1:2) & 43.82 & 99.17 & 41142 & 89476 & 2.18 \\
\hline$M_{4}$ - Maize + Sunnhemp as BM (1:1) & 40.69 & 93.11 & 41038 & 81581 & 1.99 \\
\hline$M_{5}$ - Maize + Sunnhemp as BM (1:2) & 43.08 & 96.48 & 41242 & 85820 & 2.08 \\
\hline $\mathrm{M}_{6}$ - Maize + Cowpea as BM (1:1) & 36.55 & 86.45 & 41238 & 72595 & 1.76 \\
\hline $\mathrm{M}_{7}$ - Maize + Cowpea as BM (1:2) & 39.34 & 90.16 & 41510 & 77219 & 1.86 \\
\hline M8 - Maize + Dhaincha as BM (1:1) & 29.21 & 77.40 & 41188 & 60713 & 1.48 \\
\hline$M_{9}$ - Maize + Dhaincha as BM (1:2) & 31.42 & 80.16 & 41443 & 64094 & 1.55 \\
\hline S.Em \pm & 2.12 & 3.02 & - & 3976 & 0.10 \\
\hline C.D. (0.05) & 6.41 & 9.14 & - & 12023 & 0.29 \\
\hline \multicolumn{6}{|l|}{ Sub plots $(\mathbf{N})$} \\
\hline $\mathrm{N}_{1}-75 \% \mathrm{RDN}$ & 35.18 & 85.85 & 40710 & 72340 & 1.78 \\
\hline $\mathrm{N}_{2}-100 \% \mathrm{RDN}$ & 36.31 & 86.98 & 41031 & 73506 & 1.79 \\
\hline $\mathrm{N}_{3}-125 \% \mathrm{RDN}$ & 37.51 & 88.17 & 41352 & 74756 & 1.81 \\
\hline S.Em \pm & 1.56 & 1.56 & - & 2057 & 0.05 \\
\hline C.D. (0.05) & NS & NS & - & $\mathbf{N S}$ & NS \\
\hline Interaction (M x N) & & & - & & \\
\hline S.Em \pm & 3.67 & 4.87 & - & 6419 & 0.16 \\
\hline C.D. (0.05) & NS & NS & - & NS & NS \\
\hline
\end{tabular}

Note: GM - Green manuring, BM - Brown manuring

Rate: Maize - Rs 1325/ q (2013-14) and Rs. 1310/q (2014-15), Wheat - Rs.1550/q (2013-14) and Rs. 1450/q (2014-15) 
The interaction effect due to manuring treatments as well as varying levels of nitrogen did not differ significantly.

In conclusion, Sunnhemp as green manuring in 1:2 row proportion followed by sunnhemp as brown manuring 1:2 row proportions recorded significantly higher grain and stover yield of maize and also influenced on succeeding wheat crop to produce higher grain and straw yield of wheat. These treatments were known to be get higher net returns (Rs. 89,476 and Rs 85,820 ha respectively) and B:C (2.18 and 2.08 respectively) compare to other treatments. Thus, sunnhemp as green manuring in 1:2 row proportion followed by sunnhemp as brown manuring 1:2 row proportions were proved to be very effective to increase the productivity of maize - wheat cropping system under UKP command.

\section{Acknowledgement}

The senior author is thankful to University of Agricultural Sciences, Raichur for providing an opportunity to study the higher education on deputation.

\section{References}

Aslam, M., Hussain, S., Ramazan, M., and Akhtar, M., 2008. Effect of different stand establishment techniques on rice yields and its attributes. Journal of Animal and Plant Science. 18: 2-3.

Dasaraddi, S. V., 1998. Effect of in situ incorporation of legumes intercropped with maize in maize-safflower relay cropping system under rainfed condition. M. Sc. (Agri.) Thesis, University of Agricultural Sciences, Dharwad.

Gangawar, K. S., Sharma, S. K., and Tomar, O. K., 2004. Alley cropping of subabul (Leucaena leucocephala L.) for sustaining higher crop productivity and soil fertility of rice (Oryza sativa L.) wheat (Triticum aestivum L.) system in semi arid conditions. Indian Journal of Agronomy. 49 (2): 84-88.

Grewal, H. S., Kolar, J. S., and Kang, J. S., 1992. Effect of combined use of green manure and nitrogen on the productivity of maize (Zea mays L.) - wheat (Triticum aestivum L.) system. Indian Journal of Agronomy. 37: 635-638.

Jat, N. K., Ashok Kumar, and Shivadhar. 2010. Influence of Sesbania green manure with or without wheat residues and $\mathrm{N}$ fertilization on maize (Zea mays L.) wheat (Triticum aestivum L.) cropping system. Indian Journal of Agronomy. 55(4): 253-258.

Kumar, M. S., and Mukharjee, P. K., 2011. Effect of brown manuring on grain yield and nutrient use efficiency in dry direct seeded kharif rice (Oryza sativa L.). Indian Journal of Weed Science. 43(2): 61-66.

Nooli, S.S., and Chittapur, B.M., 2001. Influence of in situ green manuring of intercropped legumes on the performance of maize - safflower sequence cropping. M. Sc (Agri.) Thesis, University of Agricultural Sciences, Dharwad.

Mankotia B.S., 2007. Effect of fertilizer application with farmyard manure and in situ green manures in standing rice (Oryza sativa L.) - Wheat (Triticum aestivum L.) cropping system. Indain Journal of Agricultural Sciences.; 77(8): $512-515$.

Samar Singh., Ladha, J. K., Gupta, R. K., Bhushan, L., Rao, A. N., Shiva Prasad, B., and Singh, P., 2007. Evaluation of mulching, intercropping with Sesbania and herbicide use for weed management in dry seeded rice (Oryza sativa L.). Crop Protection. 26: 518-524. 
Satyaprakash and Phoolchand., 2011. Brown manuring in sugarcane for high production. Progressive Agriculture. 11: 194-197.

Sharma, S.N., and Prasad, R., 2001. Effect of wheat, legume and legume enriched wheat residues on the productivity and nitrogen uptake of rice - wheat cropping system and soil fertility. Acta Agronomica Hungarica. 49 (4): 369378.
Sharma, D. P., Sharma, S.K., Joshi, P.K., Singh, S., and Singh, G., 2008. Resource conservation technologies in the reclaimed soils. Central Soil Salinity Research Institute, Karnal Technical Bulletin 1.

Tanwar S. P. S., Singh, A. K. and Joshi, N., 2010, Changing environment and sustained crop production; A challenge for agronomy. Journal of Arid Legumes. 7(2): 91-100.

\section{How to cite this article:}

Hiremath, K.A., A.S. Halepyati, M.A. Bellakki, B.M. Chittapur, P.H. Kuchanur, B.M. Dodamani and Ameregouda. 2019. Effect of Manuring Techniques on Soil Health, Yield and Economics of Maize-Wheat Cropping System under UKP Command. Int.J.Curr.Microbiol.App.Sci. 8(02): 204-214. doi: https://doi.org/10.20546/ijcmas.2019.802.025 